УДК 37.013

DOI:

Володимир Бутенко, член-кореспондент Національної академії педагогічних наук України, доктор педагогічних наук, професор,

Херсонський факультет Одеського державного університету внутрішніх справ Наталія Бутенко, кандидат педагогічних наук, доцент Херсонського державного університету

\title{
ЕСТЕТИЧНА СВІДОМІСТЬ ЯК УМОВА ОРГАНІЗАЦІЇ ЖИТТЕДІЯЛЬНОСТІ ОСОБИСТОСТІ ЗА ЗАКОНАМИ КРАСИ
}

У статті представлена характеристика ичивілізаційного підходу до розвитку українського суспільства, в якому гармонізуються сочіальні, економічні, культурологічні процеси, зміцнюється роль особистості, спроможної виявляти естетичне ставлення до навколишньої дійсності; здатність сприймати, оцінювати, творчо осмислювати та втілювати на практиці естетичні цінності. Головна увага зосереджена на ролі естетичної свідомості у розвитку гармонійної особистості, можливостях впливу естетичної свідомості на різновиди життєдіяльності людини за законами краси.

Ключові слова: естетична свідомість; розвиток гармонійної особистості; різновиди життєвої діяльності.

Jim. 5.

Volodymyr Butenko, Corresponding Member of the National Academy of Pedagogical Sciences of Ukraine, Doctor of Sciences (Pedagogy), Professor,

Kherson Faculty of Odessa State University of Internal Affairs Nataliya Butenko, Ph.D.(Pedagogy), Associate Professor Kherson State University

\section{AESTHETIC CONSCIOUSNESS AS A CONDITION FOR ORGANIZING THE LIFE OF THE INDIVIDUAL ACCORDING TO THE LAWS OF BEAUTY}

The article focuses on the suitability of civilizational approach introduction to the development of Ukrainian society, which harmonizes social, economic, industrial, cultural-creative processes, strengthens the role of the individual, able to show the aesthetic attitude to the surrounding reality and the ability to deeply perceive, evaluate, creatively comprehend and put into practice aesthetic values.

According to the results of theoretical analysis, the contribution of scientists to the study of the aesthetic factors influence in the system of individual education, it is highlighted that issues of aesthetic content acquire relevant character and perceived as necessary to improve the effectiveness of personal preparation for life, work, creativity, communication and self-development.

In the process of scientific research the essence and significance of aesthetic consciousness in the organization of human life is discovered, the role of aesthetic consciousness in the development of harmonious personality is clarified, the possibilities of aesthetic consciousness influence on different types of life according to the laws of beauty are highlighted.

It is noted that aesthetic consciousness needs to be understood and defined as a civilizational category, which symbolizes the gradual advancement of society on the path of progress, acquisition of qualitatively new content and forms of activity, establishment of fruitful human relations with the environment, use of significant human opportunities in self-improvement field. It is emphasized that aesthetic consciousness can motivate a person to be more developed, perfect, expressive at the level of the most important traits and qualities. It is about one's physical, psychological, spiritual and creative development.

According to the results of the research, the possibilities of the aesthetic consciousness influence on the types of personal vital activity according to the laws of beauty are highlighted, an attempt to systematically approach the analysis of this issue is revealed, the types of human vital activity according to the laws of beauty are marked out. Such types of vital activity of the individual include evaluative-interpretative, communicative-value, educationalcognitive, scientific-researching, creative-innovative, productive-industrial and self-organizing activities.

Keywords: aesthetic consciousness; a development of harmonious personality; types of vital activity.

П остановка проблеми. Цивілізаційний розвиток українського суспільства сповнений діалектичнимисуперечностями, пов’язанимиз пізнанням та освоєнням навколишньої дійсності, становленням економічної, культуротворчої, наукової, освітньої практики, формуванням найважливіших якостей і рис людини. Названі суперечності передбачають ї глибоке сприймання, осмислення, узагальнення та прийняття рішень, які б уможливили не 


\section{ЕСТЕТИЧНА СВІДОМІСТЬ ЯК УМОВА ОРГАНІЗАЦІї ЖИТТЕДІЯЛЬНОСТІ ОСОБИСТОСТІ ЗАЗАКОНАМИ КРАСИ}

гальмувати суспільний прогрес, не створювати в його розвитку додаткові суперечності, не привносити певні ускладнення та виклики, а навпаки, забезпечувати необхідні передумови для подальшого просування українського суспільства шляхом наукового, культурного, мистецького прогресу, набуття консолідованих і оптимальних рішень, спрямованих на підвищення ефективності економічних відносин, збільшення продуктивності суспільного виробництва, збагачення системи духовних цінностей.

Складність і багатоаспектність цивілізаційного поступу України у найважливіших сферах економічного, соціального, культурного, наукового, освітнього й мистецького життя залежить від багатьох чинників: зовнішніх і внутрішніх, емоційних і раціональних, колективних та індивідуальних, свідомих і підсвідомих, системних та фрагментарних, логічних і алогічних. Цей перелік може бути продовжений, ураховуючи зміст, характер, форми, способи і методи досягнення тих цілей, до яких прагне українське суспільство у своєму розвитку.

Залежно від якості суспільних рішень можна виділити декілька концептуальних підходів, а саме: прагматичний, гуманітарний і цивілізаційний. Характерною ознакою прагматичного підходу до розвитку суспільної практики є домінування фінансових, економічних, виробничих, комерційних інтересів, посилення уваги до питань, пов'язаних зі збільшенням матеріальної складової життєдіяльності окремих верств населення, прийняття рішень щодо утворення потужних економічних, виробничих структур, комплексів, систем тощо. При цьому важливо зазначити, що в межах прагматичного підходу до суспільних рішень суттєво знецінюється складова життя, пов'язана з людиною, її освітою, розвитком, дозвіллям та відпочинком. Комерціоналізація цих аспектів обмежує можливості людини у створенні умов для саморозвитку, самоосвіти, самовдосконалення, призводить до згортання суспільних програм щодо розвитку сучасної освіти, системи охорони здоров'я, занять фізичною культурою і спортом, культуротворчої, мистецької діяльності. За таких обставин ставлення людини до навколишньої дійсності втрачає духовну забарвленість, спрощується за своїм змістом і формою, стає примітивним i безперспективним щодо подальшого розвитку та впровадження на практиці.

Характеризуючи гуманітарний підхід до розвитку суспільної практики важливо зазначити, що акцент зміщується у бік суб'єктивної складової життєдіяльності людини, посилюється увага широкої громадськості до питань, що пов'язані з правовими, морально-етичними, конфесійними відносинами, становленням різних політичних систем, забезпеченням прав і свобод людини, їі можливостей самореалізації та самоствердження у певних сферах культури, дозвілля, спорту тощо.

Згідно з гуманітарним підходом у розв'язанні соціальних питань проголошується пріоритетним питання людини, посилюється принцип людиноцентризму в освіті, приймаються рішення щодо створення адекватних умов для розвитку індивідуальних сил, можливостей та здібностей у сфері освіти, науки, мистецтва та спорту. Водночас у межах гуманітарного підходу суттєво мінімізуються питання щодо участі людини у продуктивному процесі, пов'язаним з виробництвом, працею, виготовленням матеріальних цінностей, виконанням функцій щодо обслуговування технічних приладів, здійсненням трудових операцій, побутової праці тощо. За таких обставин у людини формується споживацьке ставлення до життя, знецінюються зміст, форми та способи продуктивної діяльності, втрачається інтерес та бажання брати участь у виробничих процесах.

На відміну від прагматичного та гуманітарного підходів заслуговує на увагу підхід до суспільного розвитку, основою якого є циивілізаційний поступ українського суспільства, в якому гармонізуються соціальні, економічні, виробничі, культуротворчі процеси, зміцнюється роль особистості, спроможної виявляти естетичне ставлення до навколишньої дійсності здатної глибоко сприймати, оцінювати, творчо осмислювати на практиці естетичні цінності. При цьому важливо зазначити, що відповідно до цивілізаційного підходу перед людиною постає вимога щодо організації життєдіяльності за законами краси, вияву спроможності втілювати у процесі спілкування, навчання, праці та творчості ідеї естетичного змісту, забезпечувати важливі прояви життя на основі взаємозв'язку їх змісту і форми, зовнішнього та внутрішнього, емоційного й раціонального, практичного і теоретичного, колективного та індивідуального, традиційного й інноваційного.

Мета та завдання. Усвідомлення потреби системного вивчення зазначеної проблеми зумовило визначення мети наукового пошуку. Вона полягає в тому, щоб теоретично обгрунтувати естетичну свідомість як необхідну умову організації життєдіяльності особистості за законами краси.

До основних завдань віднесено такі:

1. Розкрити сутність та значення естетичної 


\section{ЕСТЕТИЧНА СВІДОМІСТЬ ЯК УМОВА ОРГАНІЗАЦЇ̈ЖИТТЕДІЯЛЬНОСТІ ОСОБИСТОСТІ ЗА ЗАКОНАМИКРАСИ}

свідомості в організації життєдіяльності особистості за законами краси.

2. 3'ясувати роль естетичної свідомості у розвитку гармонійної особистості.

3. Висвітлити можливості впливу естетичної свідомості на різновиди життєдіяльності особистості за законами краси.

Аналіз основних досліджень. У сучасній науковій практиці накопичено теоретичний досвід осмислення ролі естетичних чинників у системі освіти і виховання особистості, а також визначення їхнього впливу на найважливіші складники духовного світу учнівської та студентської молоді. Йдеться про наукові дослідження, пов'язані 3 формуванням естетичних якостей особистості, а саме: формування музично-естетичних орієнтацій майбутніх учителів (О. Пономарьова), естетичне виховання підлітків засобами художньої літератури В. Біруля, формування естетичного досвіду вчителя (Н. Бутенко); естетичне виховання студентської молоді у процесі клубної роботи (Ю. Максимчук); формування естетичного ставлення до корекційно-педагогічної праці (В. Бутенко, В. Білан); роль культурно-освітнього середовища навчального закладу в системі естетичного виховання молоді (В. Бутенко); формування системи естетичних цінностей майбутніх учителів (О. Софіщенко); формування естетичної культури майбутніх дизайнерів у закладах вищої освіти (В. Томашевський) тощо.

За результатами проведених ученими досліджень можемо констатувати, що в системі освіти питання естетичного змісту набувають певної актуальності, усвідомлюються як необхідні для підвищення ефективності підготовки особистості до життя, праці, творчості та спілкування. Учені цілком слушно наголошують на важливості таких аспектів, як: підготовка молоді до сприймання художньо-естетичних цінностей (О. Рудницька); самостійна естетична оцінка творів мистецтва (Л. Коваль); творча інтерпретація творів художньої літератури (Л. Бутенко); організації художньо-творчої діяльності дитячого музичного колективу (Ю. Шевченко); розвитку естетичних якостей підлітків в умовах взаємодії школи і сім'ї (I. Слятіна); естетичне виховання студентської молоді у процесі культуротворчої діяльності (І. Корольова) тощо.

У контексті зазначених досліджень певне місце займають питання естетичної свідомості як умови організації життєвої діяльності особистості за законами краси. Можемо бачити, що вказана проблема перебуває у центрі уваги вчених, що дає змогу розкривати окремі аспекти соціально-історичної, культурологічної, психологічної та педагогічної детермінації естетичної свідомості. Водночас слід зауважити, що наукове вивчення означених вказаної проблеми ще не забезпечило iii достатнього осмислення. Адже йдеться переважно про зовнішні чинники впливу на формування естетичної свідомості і при цьому не дається достатньо чіткої відповіді на питання, що стосуються ролі естетичної свідомості у забезпеченні життєдіяльності особистості за законами краси.

У дослідженні зазначеної проблеми залишаються недостатньо з'ясованими декілька аспектів, зокрема:

- сутність естетичної свідомості як цивілізаційної категорії;

- можливості естетичної свідомості у забезпеченні життєдіяльності особистості за законами краси;

- роль естетичної свідомості у розвитку гармонійної особистості;

- вплив естетичної свідомості на найважливіші сфери життєдіяльності особистості.

Виклад основного матеріалу. Естетична свідомість $є$ тим поняттям, яке знайшло певне осмислення у суспільній практиці. Воно використовується у системі суспільних відносин, у сфері культуротворчості, у процесі освіти, побуту, дозвілля, є показником розвитку людини, іiі духовності, культури, творчості. До поняття естетичної свідомості звертаються представники таких галузей науки, як філософія, естетика, етика, культурологія, психологія, педагогіка та ін. Усе це переконливо засвідчує не лише наявність суспільного інтересу до поняття естетичної свідомості, але й прагнення сучасної практики якомога глибше осмислити його сутність та значення.

В історії суспільного розвитку знайшли своє відображення окремі погляди філософів, учених, культурологів, митців щодо естетичної свідомості. Це дало підставу інтерпретувати естетичну свідомість як об'єктивно-ідеалістичне, суб'єктивно-об'єктивне, метафізико-матеріалістичне та діалектично-матеріалістичне явище. В умовах сьогодення можна спостерігати звернення людей до цього поняття 3 метою надання певної характеристики естетичної свідомості як складової суспільного, економічного, культурного, освітнього життя. Безперечно, за таких обставин естетична свідомість як поняття набуває певного тлумачення, узагальнюється, конкретизується, визначається у контексті тих координат, які суспільство та окрема особистість вважають важливими, необхідними й актуальними. 


\section{ЕСТЕТИЧНА СВІДОМІСТЬ ЯК УМОВА ОРГАНІЗАЦЇ ЖИТТЕДІЯЛЬНОСТІ ОСОБИСТОСТІ ЗА ЗАКОНАМИ КРАСИ}

Не вдаючись у деталі та різновиди суджень 3 цього питання вважаємо доцільним підкреслити, що естетична свідомість потребує осмислення й визначення передусім як цивілізаційна категорія, яка символізує собою поступове просування суспільства шляхом прогресу, набуття якісно нового змісту та форм діяльності, встановлення плідних відносин людини 3 навколишнім середовищем, використання значних можливостей та потенціалу людини у сфері саморозвитку та самовдосконалення. Спираючись на діалектикоматеріальну філософію та відповідну методологію наукового пізнання, можемо засвідчити, що естетична свідомість може бути представлена як свідчення тих цивілізаційних змін, які мають місце у сфері економічного, соціального, наукового, культурного,особистісного розвитку.

Наявність розвиненої естетичної свідомості людини $\epsilon$ свідченням іiі спроможності безпосередньо сприймати, аналізувати, оцінювати, робити необхідні висновки щодо цивілізаційного розвитку суспільства. Йдеться, зокрема, про можливості особистості належно ставитися до конструктивних змін, що оптимізують суспільне виробництво, посилюють економічну складову суспільного життя, демонструють систему правових, моральних, політичних відносин, зміцнюють соціальні, родові, сімейні форми взаємодії між людьми. Важливо зауважити, що естетична свідомість особистості має значний потенціал у сфері пізнання та освоєння навколишньої дійсності за законами краси. Саме тому їі слід вважати показником того, що особистість не залишається осторонь досягнень у сфері наукового пізнання, розвитку культурномистецької сфери, а також індивідуального розвитку та вияву творчого потенціалу.

Отже, естетична свідомість є тим поняттям, яке важливо усвідомлювати в контексті цивілізаційних змін, які відбуваються на широкому суспільному грунті і засвідчують поступове просування як суспільства загалом, так і окремої людини шляхом організації життєдіяльності за законами краси. Зауважимо, що закони краси відображають діалектико-матеріалістичні зміни не лише у сфері навколишнього середовища, але й в системі естетичної свідомості особистості, що зумовлює необхідність іiі удосконалення, збагачення та розвитку. Саме тому так гостро й актуально сприймається питання щодо ролі естетичної свідомості особистості у їі житті, праці та творчості. Завдяки естетичній свідомості людина отримує можливість відчувати й усвідомлювати свою причетність і водночас відповідальність за підтримку і втілення цивілізаційних здобутків як у повсякденному житті, так і в широкому аспекті суспільних відносин, культуротворчості та самовдосконалення.

У науковій літературі з філософії та естетики вчені досліджують естетичну свідомість як важливий прояв пізнання прекрасного в дійсності та мистецтві. На думку дослідників (О. Бєляєв, Л. Новікова, В. Толстих та ін.), естетична свідомість $є$ однією з форм суспільної свідомості, яка, на відміну від інших форм (політичної, правової, моральної, релігійної, наукової) $є$ відображенням дійсності та її оцінкою з позиції естетичного ідеалу. Об'єктом відображення естетичної свідомості, на думку вчених, виступає світ людини, тобто природна та соціальна дійсність, яка була освоєна на рівні соціальнокультурного досвіду. Цю дійсність особистість переводить в естетичний план, по-новому організовуючи, посилюючи та оцінюючи з погляду повноти їі життєвих проявів та суб'єктивної значущості.

Ураховуючи зазначене, вважаємо доцільним з'ясування ролі естетичної свідомості у розвитку гармонійної особистості. Сьогодні цей аспект набуває особливого значення. Адже йдучи шляхом цивілізаційного розвитку, людина покликана на власному життєвому прикладі засвідчити відповідні позитивні зміни, набути тих якостей, які б підтверджували їі прагнення відповідати естетичним вимогам у всьому, що стосується її особистісного розвитку.

На жаль, в умовах сучасної практики питання розвитку гармонійної особистості ще не набуло достатньої суспільної уваги та підтримки. Про це рідко йдеться в засобах масової інформації, вказане питання недостатньо висвітлюється на сторінках педагогічної літератури, не актуалізуються завдання розвитку гармонійної особистості в закладах освіти. Перевага надається питанням, які мають переважно прикладний характер і не стосуються того, що характеризує сутність гармонійної особистості, їі спроможність наближати до естетичної виразності основні складові ¥ї фізичного, психологічного, духовного та творчого розвитку.

Гармонійна особистість $є$ якісним показником iii розвитку, який не з'являється спонтанно. Він передбачає відповідні зусилля, цілеспрямовані дії, а також досягнення бажаних змін на рівні особистості, які відповідали б сучасним естетичним вимогам. Саме тому особливої гостроти й актуальності набуває естетична свідомість, яка може спонукати особистість бути більш розвиненою, досконалою, виразною на рівні найважливіших рис та якостей. Йдеться, зокрема, 


\section{ЕСТЕТИЧНА СВІДОМІСТЬ ЯК УМОВА ОРГАНІЗАЦІЇЖИТТЕДІЯЛЬНОСТІ ОСОБИСТОСТІ ЗА ЗАКОНАМИ КРАСИ}

про такі складові розвитку гармонійної особистості, як іiі фізичний, психологічний, духовний та творчий розвиток.

Естетична свідомість, за наявності їі належного розвитку, може бути дієвим чинником впливу на ставлення особистості до їі фізичного здоров'я, самопочуття, розвитку фізичних якостей та фізичної культури загалом, дотримання відповідного регламенту харчування, відпочинку, фізичних навантажень, виконання фізичних вправ, які спроможні позитивно забезпечувати важливі аспекти здорового й активного способу життя. Естетична свідомість спроможна в силу іiі емоційної чутливості й виразності спонукати особистість до фізичного самовдосконалення, регулярних занять фізичною культурою і спортом, до протидії шкідливим для здоров'я звичкам.

Естетична свідомість відкриває перед людиною бажані перспективи досягнення фізичної краси і досконалості, наближає до естетичного ідеалу фізично досконалої й розвиненої людини, для якої фізична краса $\epsilon$ основою та умовою плідного життя.

Розвиток гармонійної особистості передбачає належне ставлення до їі психологічних якостей. Йдеться про такі прояви психіки, як почуття, мислення, сприймання, увага, уява та ін. Результати наукових досліджень підтверджують наявність значних можливостей впливу на психологічні властивості особистості на основі використання можливостей естетичної свідомості та іiї залучення до вказаного процесу. Усвідомити якісні прояви психологічної культури особистості можливо лише на конкретних прикладах того, і в який спосіб може психологічно реагувати людина, наділена розвиненим почуттям прекрасного, розумінням сутності й виразності інтелектуальних дій та рішень, спроможна виявляти власну реакцію на зовнішні подразники, ураховуючи тї забарвленість, доцільність, відповідність зовнішнім і внутрішнім аспектам.

Без естетичної свідомості важко уявити красу духовного світу особистості. Адже йдеться про звернення до системи моральних, політичних, релігійних, наукових та правових цінностей. Усі вони несуть певне змістове навантаження, посилюють увагу особистості до актуальних питань правовідносин, моральних, політичних, науково-світоглядних рішень та висновків. Для їх повноцінного сприймання й осмислення важливою є естетична свідомість, яка уможливлює освоєння ïx у діалектичних зв'язках та співвідношеннях внутрішнього і зовнішнього, загального i одиничного, емоційного і раціонального, минулого і сьогодення, теоретичного і практичного, прогресивного та консервативного, традиційного й інноваційного.

Естетична свідомість $є$ важливим чинником розвитку творчих сил, можливостей та здібностей особистості. Спираючись на власні естетичні почуття, уявлення та поняття прекрасного, смакові уподобання, естетичні інтереси, потреби й ідеали, особистість отримує можливість безпосереднього реагування на художні цінності, ї творчого осмислення, тлумачення та інтерпретації. На основі естетичної свідомості відкривається простір для генералізації художньоестетичного досвіду, його транспозиції з метою активного використання у процесі творчої діяльності, акумулювання творчих ідей та рішень.

Отже, у сфері розвитку гармонійної особистості естетична свідомість відіграє важливу роль. У ній зосереджується необхідний для особистості досвід емоційного, інтелектуального й продуктивного освоєння навколишньої дійсності та мистецтва, закріплюються необхідні почуття, уявлення, поняття, ціннісні орієнтації, що забезпечують плідний розвиток фізичних, психологічних, духовних, творчих сил та можливостей особистості; актуалізується бажання жити і діяти за законами краси.

У контексті дослідження зазначеної проблеми виникає необхідність висвітлення можливостей впливу естетичної свідомості на різновиди життєдіяльності особистості за законами краси. Актуалізація цього питання зумовлена тим, що естетична свідомість $є$ функціональною категорією, спроможною впливати не лише на якісні параметри розвитку гармонійної особистості, але й на найважливіші різновиди іï життєдіяльності за законами краси. Саме тому цілком зумовленим видаються інтерес широкої громадськості (освітян, учених, працівників сфери культури та ін.) до тих аспектів вказаної проблеми, які засвідчують детермінацію життєдіяльності та iii розвиток під впливом естетичної свідомості особистості. До таких різновидів життєдіяльності особистості нами віднесено: оцінноінтерпретаційну, комунікаційно-ціннісну, освітньопізнавальну, науково-пошукову, креативноінноваційну, продуктивно-виробничу та самоорганізаційну.

У життєвому просторі особистості доводиться тісно взаємодіяти з різними явищами, процесами та цінностями. Ця взаємодія передбачає вияв активного ставлення людини до вказаних проявів, які мають місце у сфері мистецтва, культури, освіти, політики, моралі, права, релігії. Особистість не може залишатися пасивною у 


\section{ЕСТЕТИЧНА СВІДОМІСТЬ ЯК УМОВА ОРГАНІЗАЦЇ̈ЖИТТЕДІЯЛЬНОСТІ ОСОБИСТОСТІ ЗА ЗАКОНАМИ КРАСИ}

визначенні їх ціннісного змісту, духовної спрямованості, орієнтаційної якості, а тому покликана певним чином реагувати на них шляхом безпосереднього сприймання, оцінювання, осмислення, аналізу й інтерпретації. Під впливом естетичної свідомості відбувається розвиток оцінно-інтерпретаційної діяльності. Людина отримує можливість самостійно визначати естетичну складову окремих життєвих проявів, процесів, явищ та здобутків. Як зазначає Л. Бутенко “на основі культурологічного підходу інтерпретація художніх творів визначається як художньо-творча діяльність у сфері мистецтва, завдяки якій передається естетичне ставлення до навколишньої дійсності, розкриваються нові грані художньо образного відображення окремих предметів та явищ, утверджується гуманістична роль та функції художніх цінностей у суспільному розвитку та життєдіяльності людини" [2].

Важливим проявом життєдіяльності людини є комунікаційно-ціннісна діяльність, суть якої полягає у встановленні активного й дієвого зв'язку з важливими сферами життя людини. Йдеться, зокрема, про комунікаційно-ціннісні зв'язки особистості з проявами прекрасного у сфері відпочинку, культуротворчості, мистецтва, занять фізичною культурою і спортом, міжособистісного спілкування, взаємодії в умовах праці, навчання, творчості.

Зміст, характер, рівень та способи спілкування людини зі світом прекрасного мають відповідати сучасним можливостям і не обмежуватися лише вузькою сферою життя. Особистості мають бути зрозумілими і сприйнятливими прояви прекрасного у процесі таких різновидів спілкування, як побутове, сімейне, корпоративне, професійне, художне, наукове, політичне, конфесійне, моральноетичне та ін. Саме тому вплив естетичної свідомості на комунікаційно-ціннісну діяльність людини має набувати системного й послідовного характеру. Як зазначає В. Кремень, “корективи слід внести і в таку важливу сферу, як формування системи цінностей особистості. Слід всім зрозуміти, що утвердження цінностей, які вже віджили свій вік або завершують його, дуже негативно впливає не тільки на сутність особистості, адекватність іiі історичному часу, а й , безумовно, на життєвий шлях людини і характер суспільства в цілому" [5].

У житті людини особливе місце займає освітньо-пізнавальна діяльність, покликана відкривати нові знання, формувати науковий, художній, естетичний світогляд, створювати умови для забезпечення особистості необхідним досвідом. В умовах сьогодення освітня практика покликана бути активним провідником людини у світ прекрасного та піднесеного, всього, що збагачує почуття, знання, поняття, уявлення людини, робить їі активним учасником освоєння світу естетичних цінностей.

Саме тому так гостро постає проблема формування естетичної свідомості особистості, спроможної естетизувати освітньо-пізнавальний процес, робити його не лише корисним, але й емоційно забарвленим, захопливим, приємним 3 погляду перебування людини в освітньому середовищі закладу освіти. Як зазначають В. Бутенко, Г. Троцко, Г. Шевченко, “культурноосвітнє середовище навчального закладу набуває естетичного змісту і характеру за допомогою мистецтва. Саме тому в навчальному і виховному процесі важливо якомога частіше звертатися до світу прекрасного і за участю художньоестетичного матеріалу збагачувати процес пізнання, спілкування, відпочинку тощо" [1]

У процесі цивілізаційного розвитку українського суспільства має посилюватися роль науково-пошукової діяльності. Адже йдеться про ствердження у структурі життя кожної людини позитивного й відповідального ставлення до науки, наукової практики, діяльності вчених та отриманих ними результатів дослідницької діяльності. Саме тому сьогодні важливо усвідомити науковопошукову діяльність як таку, що сповнена почуття прекрасного, спроможна викликати позитивні емоції і переживання, спонукає людину до освоєння навколишньої дійсності за законами краси.

Розвиток естетичної свідомості людини покликаний вивести сприймання наукової сфери на рівень високого захоплення, співпереживання, отримання насолоди від усвідомлення результатів розкриття об'єктивних закономірностей та залежностей, що існують в природі, культурі, соціумі та ін. Наукові досягнення важливо оцінювати 3 урахуванням не лише їх результативності, але й якості та характеру відображення у відповідних формах (монографіях, посібниках, наукових звітах тощо). Це дасть можливість вважати науково-пошукову діяльність естетичною, сповненою проявами прекрасного, виразного, гармонійного, системного, структурованого.

Достатньо вагомою $є$ роль естетичної свідомості в організації креативно-інноваційної діяльності людини. Адже йдеться про діяльність, в якій особливе місце займають такі якості особистості, як почуття, емоції, сприймання, уява, фантазія, передбачення та ін. Відомо, що людина у своєму житті прагне 


\section{ЕСТЕТИЧНА СВІДОМІСТЬ ЯК УМОВА ОРГАНІЗАЦЇЖИТТЕДІЯЛЬНОСТІ ОСОБИСТОСТІ ЗА ЗАКОНАМИ КРАСИ}

позиціонувати себе творцем, спроможним до нових і рішучих дій, пов'язаних з моделюванням життєвих ситуацій та умов їх реалізації на практиці. Спираючись на естетичну свідомість, людина отримує реальні можливості для діяльності, яка може мати нетрадиційний характер, сміливі й неординарні рішення, використання способів, методів та форм досягнення результатів креативного, інноваційного змісту. Це може бути характерним у сфері мистецької, культурологічної, наукової та інших видів життєдіяльності людини.

В умовах сьогодення набуває відчутної гостроти питання організації продуктивновиробничої діяльності за законами краси, з урахуванням принципів та вимог дизайну. Виробнича продукція та процес її виготовлення повинен мати не лише ефективний, але й естетичний характер, відповідати сучасним естетичним смакам, ідеалам, цінностям тощо. Для цього важливо створювати відповідні умови, що забезпечують посилення естетичних вимог, дотримання естетичних норм та принципів продуктивно-виробничої діяльності.

Естетична свідомість потрібна для багатьох видів професійної діяльності. Адже вона спонукає лікаря, вчителя,, інженера, менеджера, митця діяти у такий спосіб, щоб їх професійна діяльність викликала позитивні емоції, забезпечувала естетичну атмосферу, сповнену поваги до виконаної роботи. Як зазначає С. Гончаренко, “естетика поведінки - риси прекрасного у вчинках і діях людини: в ії ставленні до праці й суспільства, в іiї манерах і вигляді, у формах спілкування 3 людьми" [4].

Безперечно, вплив естетичної свідомості пов'язаний також із само організаційною діяльністю особистості, 1ї спроможністю забезпечувати самоорганізацію власних дій, вчинків, відносин з іншими людьми за законами краси. На жаль, про цей аспект відносин естетичної свідомості й життєвої діяльності людини ще мало написано в літературі. Проте, важливість розв'язання цього питання не зменшується. Як зазначає Н. Бутенко, “серед факторів, що впливають на виникнення естетичного досвіду слід виділити ті, що пов'язані 3 процесом самовираження особистості. Адже людина прагне замислитися не лише над сутністю того, що сприймає в житті, але й характером саморозвитку і збагачення духовного потенціалу, творчих можливостей тощо” [3].

Опора на естетичну свідомість забезпечує механізм самоорганізації таких якостей людини, як іiі професійна культура, прагнення до самовдосконалення і саморозвитку, досягнення належного рівня самоконтролю за діями та прийняттям відповідних рішень. На цій основі людина активно звертається не лише до зовнішніх чинників впливу, але й ураховує власний естетичний досвід, спирається на особистісні напрацювання у сфері естетичного пізнання.

Зазначене дає підставу констатувати, що естетична свідомість має тісні зв'язки найважливішими видами життєвої діяльності особистості. Її вплив позначається на змісті, характері, способах організації оцінноінтерпретаційної, комунікаційно-ціннісної, освітньо-пізнавальної, науково-пошукової, креативно-інноваційної, продуктивно-виробничої та самоорганізаційної діяльності.

Висновки. Теоретичний аналіз досліджуваної проблеми дає змогу зазначити, що естетична свідомість є важливою умовою організації життєдіяльності особистості за законами краси. Вона забезпечує розвиток гармонійної особистості, впливає на становлення і збагачення iii фізичних психологічних, духовних, творчих сил $\mathrm{i}$ можливостей. Водночас естетична свідомість тісно пов'язана 3 процесом життєдіяльності людини, такими її різновидами, як оцінноінтерпретаційний, комунікаційно-ціннісний, освітньо-пізнавальний, науково-пошуковий, креативно-інноваційний, продуктивно-виробничий та самоорганізаційний.

Подальший науковий пошук передбачає аналіз механізму дії естетичної свідомості та різновиди iii життєвої діяльності за законами краси.

\section{ЛІТЕРАТУРА}

1. Бутенко В. Г. Роль культурно-освітнього середовища навчального закладу в системі естетичного виховання молоді. Час мистецькой освіти. Харків, 2013.

2. Бутенко Л. В. Учитель літератури: вияв творчості й краси. Підготовка майбутніх учителів літератури до інтерпретаиії художніх творів. Монографія. Херсон, 2008.

3. Бутенко Н. І. Естетичний досвід в системі професійної діяльності вчителя. Формування естетичного досвіду вчителя. Херсон, 1996.

4. Гончаренко С.У. Український педагогічний енциклопедичний словник. Рівне, 2011.

5. Кремень, В.Г Якісна освіта і нові вимоги часу. Педагогічна $і$ психологічна науки в Україні. Теорія та історія педагогіки. 2007.

\section{REFERENCES}

1. Butenko, V.H. (2013). Rol kulturno-osvitnoho seredovyshcha navchalnoho zakladu v systemi 
estetychnoho vykhovannia molodi [The role of the cultural and educational environment of the educational institution in the system of aesthetic education of youth]. Time for art education. [in Ukrainian].

2. Butenko, L.V. (2008). Uchytel literatury: vyiav tvorchosti y krasy. Pidhotovka maibutnikh uchyteliv literatury do interpretatsii khudozhnikh tvoriv. Monohrafiia [Teacher of literature: a manifestation of creativity and beauty]. Preparing the future teachers of literature for the interpretation of works. Kherson.[in Ukrainian].

3. Butenko, N.I. (1996). Estetychnyi dosvid v systemi profesiinoi diialnosti vchytelia [Aesthetic experience in the system of professional activity of a teacher]. Formation of aesthetic experience of works of art. Kherson.[in Ukrainian].

4. Honcharenko, S.U. (2011). Ukrainskyi pedahohichnyi entsyklopedychnyi slovnyk [Ukrainian pedagogical encyclopedic dictionary]. Rivne. [in Ukrainian].

5. Kremen, V.H. (2007). Yakisna osvita i novi vymohy chasu [Quality education and new requirements of time]. Pedagogical and psychological sciences in Ukraine. Theory and history of Pedagogy. [inUkrainian].

Стаття надійшла до редакції 15.08.2020

УДК 37. 013

DOI:

Галина Білавич, доктор педагогічних наук, професор кафедри педагогіки початкової освіти ДВНЗ “Прикарпатський наџіональний університет імені Василя Стефаника"

\section{ЕНВАЙРОНМЕНТАЛЬНА ОСВІТА ДЛЯ СТАЛОГО РОЗВИТКУ У ВИМІРІ ЮНЕСКО КРІЗЬ ПРИЗМУ ПІДРУЧНИКОТВОРЕННЯ}

Розглянуто питання енвайронментальної освіти для сталого розвитку у вимірі ЮНЕСКО крізь призму підручникотворення. Зазначено, щуо енвайронментальна освіта розвивається не лише як теорія, а радше як певна практика, спрямована на формування екологічно орієнтованої т. зв. життєвої політики суспільства. Підручники в галузі енвайронментальної освіти пропонують конкретні иляхи природозбереження, гармонійноі взаємодї особи із природою, орієнтують на подальшу гуманну діяльність у довкіллі, а також забезпечують енвайронментальні знання, спрямовані на формування екологічно орієнтованого світогляду; засвоєння системи знань у галузі взаємодії природи і суспільства; виховання екогуманістичного світосприйняття особистості; проєктують розвиток енвайронментального мислення, формування відповідних переконань особистості; формування енвайронментальної поведінки та культури.

Ключові слова: енвайронментальна освіта; підручники; сталий розвиток суспільства; екологічна освіта; ЮНЕСКО.

Jim. 15.

Halyna Bilavych, Doctor of Sciences (Pedagogy), Professor of the Pedagogy of Primary Education Department, State Pedagogical University

"Vasyl Stefanyk Precarpathian National University"

\section{ENVIRONMENTAL EDUCATION FOR SUSTAINABLE DEVELOPMENT FROM THE UNESCO PERSPECTIVE THROUGH THE PRISM OF TEXTBOOK CREATION}

Foreign scholars consider environmental education as an ideology for the human civilization survival, a condition for sustainable development. Sustainable development is a complex and multifaceted concept. It is about such economic development, which is comprehensively balanced and which contains great requirements for environmental protection, environmental security, social justice; it ensures the elimination of exploitation, poverty, discrimination, and so on. The UNESCO Strategy for Education for Sustainable Development emphasizes that as of today, responsibility for the further development of humanity lies on all the citizens, children, youth and adults who are responsible for the environment. And the issues of its protection can be successfully resolved only with the participation of the general public in this process. Therefore, everyone should have access to information, including textbooks, and be able to participate in the environmental decisions. The key functions of textbooks in the field of environmental education are the acquisition of environmental knowledge by children and youth, creating a basis for the formation of a person capable of making appropriate decisions and acting in the interests of environmental protection and sustainable development of the mankind.

The article covers relevant issues of environmental education for sustainable development from the UNESCO perspective through the prism of textbook creation. It is noted that environmental education is developing not only 